\title{
Comparison of Lung Tumorigenesis Induced by Urethan in Athymic Nude Mice and Euthymic Littermates
}

\author{
Shigeru KOBAYASHI, Hiroshi OTSU, and Yuko NODA \\ Division of Physiology and Pathology, National Institute of Radiological Sciences, \\ 4-9-1 Anagawa, Inage-ku, Chiba-shi, Chiba 263, Japan
}

(Received 11 August 1993/Accepted 25 January 1994)

\begin{abstract}
Athymic $(n u / n u)$ and euthymic $(n u /+)$ mice were intraperitoneally given doses of 0.25 to $1.5 \mathrm{mg} / \mathrm{g}$ body weight of urethan at the age of 14 to 16 days. Dose-response relationship and sequential changes in lung tumorigenesis induced by urethan in athymic mice were compared with those in euthymic littermates. The urethan dose-response relationship in lung tumorigenesis of the $n u / n u$ mice was almost the same as that in the $n u /+$ mice. Incidence and multiplicity of the lung tumors were investigated sequentially 28 days to 12 months after urethan injection. They showed similar indexes in the two phenotypically different mice at varying periods after $0.5 \mathrm{mg} / \mathrm{g}$ body weight urethan treatment (incidences of 4.8 and 4.4 tumors/mouse and 96 and $97 \%$ for $n u / n u$ and $n u /+$ mice, respectively, at 12 months after treatment). This means that the length of the latent period is similar in these phenotypically different mice. It may be concluded that the immunosurveillance mechanism mediated by $\mathrm{T}$-cells does not function in the present model. - $\mathrm{KEY}$ WORDS : lung tumors, nude mice, urethan
\end{abstract}

Thomas [1] and Burnet [2] proposed that the immunosurveillance mechanism has an important role in suppressing tumor induction, with T-cells playing essential roles. According to this theory, it had been predicted that $\mathrm{T}$-cell deficient animals would be susceptible to neoplastic diseases. However, earlier studies using athymic nude mice showed discrepant results depending on the experimental conditions. This immunosurveillance theory was generally supported in tumors induced by oncogenic viruses [3-6] and spontaneous lymphoreticular neoplasms $[7,8]$. However, this was not the case in chemical carcinogenesis ; many investigators reported that the latent period and tumor incidence in nude mice treated with urethan or methylcholanthrene were not significantly different from those in euthymic control mice [8-12]. Recently, Anderson, Last-Barney and Budinger [13] and Anderson and Rice [14] described the carcinogenic response of nude mice as being more obvious than in euthymic counterparts when treated with ethylnitrosourea. In view of these conflicting results, we have attempted to reassess the carcinogenic responsiveness of nude mice in comparison with their euthymic littermates. In this study, investigations were made of the dose-response relationship and sequential changes in the development of lung tumors after urethan treatment in nude mice $(n u / n u)$ and their heterozygous littermates $(n u /+)$.

\section{Materials and Methods}

Animals: Male athymic nude mice $(n u /$ $n u)$ and their female heterozygous littermates $(n u /+)$ with a BALB/c background were supplied by the animal breeding facility of this institute, and then mated in our laboratory. Their offspring, $n u / n u$ and $n u /+$ mice, were housed in filter-topped metal cages, 6 or fewer per cage, and were maintained under specific pathogen-free conditions at $24^{\circ} \mathrm{C}, \quad 45 \sim 60 \%$ humidity, and a 12-hour light-dark cycle. They were given a commercial pellet diet, MB -1 (Funabashi Farm Co., Funabashi, Japan) and chlorinated (12 ppm) and acidified water ( $\mathrm{pH}$ 3) ad libitum. Both male and female mice were used throughout the experiments, as sex 
difference does not influence lung tumorigenesis in these mice $[3,15-18]$.

Urethan: Urethan (ethyl carbamate) was obtained from Wako Pure Chemical Industries, Ltd. (Osaka, Japan). The 2.5\% urethan solution dissolved in $0.9 \% \mathrm{NaCl}$ solution (saline) and sterilized through a $0.22 \mu \mathrm{m}$ pore filter (Millipore Co., Mass., U. S. A.). Approximately 5 -m $\ell$ aliquots of the $2.5 \%$ urethan solution were distributed into glass tubes and stored at $-20^{\circ} \mathrm{C}$ until use. The frozen solution was thawed prior to administration and used within 1 hour. All frozen stocks of the solution were used within 3 months.

Administration Route: The urethan solution was intraperitoneally (i.p.) administered. To prevent the possibility of leakage of the solution, the injector needle was inserted via the leg muscles into the abdominal cavity [17] .

Experimental Design: In experiment 1, the dose-tumor incidence relationship was examined. The $n u / n u$ and $n u /+$ mice were divided into 5 groups, ranging in number from 31 to 65 mice for each group. Mice of each group were treated with urethan or saline at 14 to 16 days of age: Group 1 (control), $0.15 \mathrm{~m} \ell$ of saline (14 days of age) ; Group 2, $0.25 \mathrm{mg} /$ $\mathrm{g}$ body weight (b.w.) of urethan (14 days) ; Group 3, $0.5 \mathrm{mg} / \mathrm{g} \mathrm{b.w.} \mathrm{(14} \mathrm{days)} \mathrm{;} \mathrm{Group} \mathrm{4,} 2$ doses of $0.5 \mathrm{mg} / \mathrm{g} \mathrm{b} . \mathrm{w}$. (14 and 15 days); and Group 5,3 doses of $0.5 \mathrm{mg} / \mathrm{g}$ b.w. $(14,15$ and 16 days). All mice were euthanized by ether anesthesia and autopsied 6 months after the treatment.

In experiment 2 , the development of lung tumor was sequentially examined. Both $n u / n u$ and $n u /+$ mice were divided into two groups. Mice of the treated group were i.p. injected with a single dose of $0.5 \mathrm{mg} / \mathrm{g} \mathrm{b}$.w. of urethan at the age of 14 or 15 days. Age-matched mice given an i.p. injection of $0.15 \mathrm{~m} \ell$ of saline served as controls. Treated animals were sacrificed and autopsied 30 and 35 days, 2, 3, 4, $6,8,10$ and 12 months after urethan-treatment. Control animals were sacrificed at 6 and 12 months after the start of the experiment.

Pathological Examination: The lung was floated on saline to allow exsanguination for a few minutes and tumor nodules in each lung lobe were then counted macroscopically or under a dissecting microscope. To confirm the reliability of the gross count, histological semi -serial sections, 1 section every $100 \mu \mathrm{m}$ in

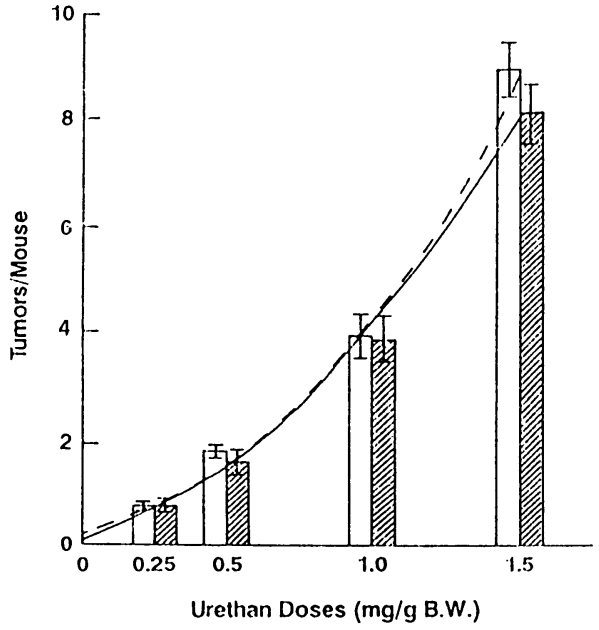

Fig. 1. Dose response of lung tumorigenesis by urethan administration in nude $(n u / n u$, shaded columns and solid line) and heterozygous $(n u /+$, open columns and broken line) mice. For details, see Materials and Methods. Each column represents average $\pm S$. E. of the tumor number in 31 to 65 mice, on average $40 \mathrm{mice} / \mathrm{col}$ umn. Neither control $n u / n u$ mice nor control $n u /+$ mice, that had been injected with saline, bore lung tumors at the time of assessment.

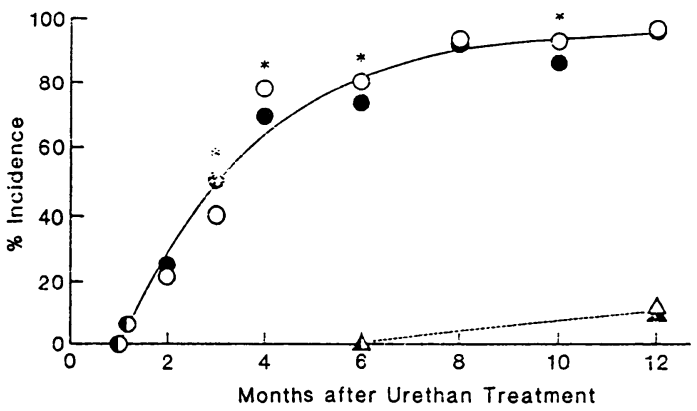

Fig. 2. Lung-tumor incidence as a function of time after urethan administration in nude $(n u / n u)$ and heterozygous $(n u /+)$ mice. 1 , Urethan administered $n u / n u ; \boldsymbol{\Delta}$, saline-injected control $n u / n u$; $\bigcirc$, urethan administered $n u /+; \triangle$, saline-injected control $n u /+$ mice. Each point represents 33 to $88 \mathrm{mice}$, an average of $49 \mathrm{mice} /$ point. Only a single line is shown because the curve for $n u / n u$ mice was not distinguishable from that for $n u /+$ mice. *There was no significant difference between $n u / n u$ and $n u /+$ mice $(\mathrm{P}>1.2$ in each case, $\chi^{2}$-test). 
thickness, of the lungs of a few mice were prepared, and the number of tumor nodules was counted under light microscopy. The number of nodules counted grossly coincided well with the microscopic count.

The lungs of all mice, and other gross lesions if present at autopsy, were fixed in $10 \%$ phosphate-buffered formalin. These sections were processed in a routine manner and stained with hematoxylin and eosin. A small number of mice died during the experiment and their carcasses were also examined as described above, but they were excluded from the present results.

Analysis of Data: Statistical analysis of the experimental data was performed using Student's $t$-test or the $\chi^{2}$-test.

\section{Results}

Dose-Response in Incidence of Lung Tumors: Lung tumorigenesis in both $n u / n u$ and $n u /+$ mice was closely linked to increases in the urethan dose (Fig. 1). Lung tumor multiplicity was proportional to the square of the urethan dose, and fit well with linear-quadratic curves in both $n u / n u$ and $n u /+$ mice ; $\mathrm{Y}=2.56 \mathrm{X}^{2}+1.38 \mathrm{X}+0.15$ and $\mathrm{Y}=3.13 \mathrm{X}^{2}+1.01$ $\mathrm{X}+0.20$, respectively, where $\mathrm{Y}$ means the number of tumor nodules/mouse and $\mathrm{X}$ means the dose of urethan $(\mathrm{mg} / \mathrm{g} \mathrm{b} . \mathrm{w}$.). These two curves coincide except for the response at a dose of $1.5 \mathrm{mg} / \mathrm{g} \mathrm{b} . \mathrm{w}$., but no significant difference was seen at this dose by $t$-test. This result may suggest that the frequency level of tumor initiation and of the ability to suppress tumor development did not differ between athymic and euthymic mice.

Sequential Observations of Lung Tumor Development : Time-dependent changes in the number of lung-tumor bearing mice and average multiplicity (number of tumor nodules/ mouse) of the lung tumors after urethan treatment are shown in Figs. 2 and 3, respectively. No tumor nodule was observed at 28 days after urethan treatment. Tumors were first detected on the 35th day in both $n u / n u$ and $n u /+$ mice. The latent period in the present study was slightly longer than that reported by Shimkin and Polissar [19]. There was no significant difference in incidence between these two phenotypically different mouse groups for a period of up to 12 months (Fig. 2). The ratio of

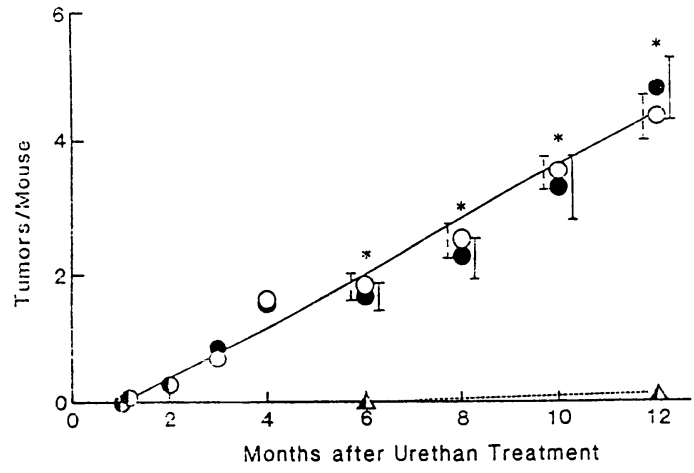

Fig. 3. Mean lung tumor numbers as a function of time after urethan administration in nude $(n u / n u)$ and heterozygous $(n u /+)$ mice (same animals as for Fig. 2). Symbols are the same as in Fig. 2. Vertical bars mean average $\pm \mathrm{S}$. E. of the tumor number, solid line for $n u / n u$ and broken line for $n u /+$ mice. ${ }^{*}$ There was no significant difference between $n u / n u$ and $n u /+$ mice ( $\mathrm{P}>0.3$ by Student' $\mathrm{s} t$-test) at any time point. Only a single line is shown for the same reason as described in Fig. 2 .

tumor bearing mice was $73 \%$ for $n u / n u$ mice and $80 \%$ for $n u /+$ mice at the 6 th month, and $96 \%$ for $n u / n u$ and $97 \%$ for $n u /+$ mice at the 12 th month of the experiment. Tumor multiplicity in $n u / n u$ mice was also comparable to that in $n u /+$ mice at all times of examination (Fig. 3). It seemed to increase almost linearly with time in both $n u / n u$ and $n u /+$ mice. Neither the incidence nor the multiplicity of lung tumors in athymic nude mice differed from those of euthymic mice at any time up to the 12 th month. These results show no shortening of the latent period in lung tumor development after urethan administration. No lung tumors were observed in control mice injected with saline at 6 months, while there were lung tumors in more than $70 \%$ of urethan-treated mice in the same period.

All of the lung tumors examined at 6 months after the urethan treatment were adenomas. At twelve months after the treatment, about $10 \%$ of the lung tumors in both athymic and euthymic mice were carcinomas. Other observed lesions were hydrometras, thymic or non-thymic lymphomas, hepatomas and skin papillomas. Their incidences, however, were too low to allow statistical analysis. 


\section{Discussion}

The results of the present study demonstrate that lung tumorigenesis by urethan in $\mathrm{BALB} / \mathrm{c}$ background nude mice, assessed by dose-response relationship, latent period, tumor incidence and multiplicity dose not differ from that of euthymic littermates. These results strongly suggest that the $\mathrm{T}$-cell mediated immunosurveillance function is not operational in this model. In addition, it was assumed that $\mathrm{NK}$ cells and macrophages also do not exert any effect on carcinogenesis, because the activities of these cells are usually fairly high in nude mice in comparison with normal mice $[20,21]$, and there was no detectable decrease of tumor incidence or tumor multiplicities in our urethan-treated nude mice. It may be concluded that the immunosurveillance system mediated by not only $\mathrm{T}$-cells but also NK cells and macrophages is not operating during urethan induction of lung tumors in mice. This coincides with the findings reported in the earlier literature on tumor development by urethan or methylcholanthrene in nude mice [8-12].

On the other hand, oncogenic virus-induced carcinogenesis [3-6] and oncogenesis by some carcinogenic chemicals, such as methylnitrosourea, ethylnitrosourea and dimethylbenzanthracene $[13,14]$, support the concept of the immunosurveillance theory. In those studies, athymic nude mice developed more tumors than euthymic mice. From the results on experimental skin tumorigenesis by nitrosourea alone or combined with $12^{-0^{-}}$ tetradecanoyl-phorbol-13-acetate (TPA) and by UV light, Anderson and Rice assumed that the skin anomalies in nude mice were a reflection of the higher susceptibility to tumorigenesis compared with normal mice [14]. The development of spontaneous lymphoreticular neoplasms has also been reported to be predominant in athymic mice $[7,8]$. It is still unclear why the immunosurveillance mechanism acts in virus-induced and spontaneous oncogenesis but not in urethan-induced tumorigenesis. More information is needed to elucidate the mechanism of tumor-development suppression.

Although the immunosurveillance mechanism did not function in the present system, more dominant tumor regulatory mechanisms may operate in mice of different phenotypes with the same genetic background. The most probable regulatory mechanism for lung tumorigenesis is the expression of gene(s) determining the susceptibility to certain oncogenic conditions. As major lung tumor regulatory genes, the "ptr" (pulmonary tumor resistance) gene [22], and the "Pas-1, -2 and -3 " (pulmonary adenoma susceptibility $-1,-2$ and -3 ) genes $[23]$, as well as other genes $[15,18,24]$, have been proposed. The $\mathrm{H}-2$ complex $[25]$, and particularly the I-A and I-E subregions $[26,27]$, have also been suggested to influence lung tumorigenicity, although their roles could not be demonstrated in our present model.

Linear-quadratic lung tumorigenic responses with increasing doses of urethan were observed in the present experiment. Similar results have been reported by other investigators [28]. Based on a comparative analysis between the urethan concentration in serum and the development of adenoma, Sichak and O'Flaherty proposed that the quadratic/linearquadratic tumorigenic response can be explained by a single-stage mutation model rather than a two-stage model [28]. The amounts of certain proximal or ultimate metabolites and the resulting nucleic acid adduct formation are closely related to urethan tumorigenesis $[17,29,30]$. In other words, carcinogenic mutation is strongly influenced by the metabolism of the chemical. It is well known that younger or newborn mice are more susceptible to urethan, in terms of the induction of lung adenoma, than older mice. This was explained by the difference in the rate of urethan elimination, i.e., the rate of urethan elimination is lower in younger than in older mice $[17,18]$. Therefore, information about not only the activating mechanisms but also the entire metabolic profile, including inactivating mechanisms and repair mechanisms of induced DNA damage, is required to fully elucidate the dose-response relationship.

We thank Drs. Toshihiko Sado and Toshiaki Ogiu for their critical and helpful comments on this manuscript, and Miss Keiko Dobashi and Mr. Seiichi Nemoto for their technical assistance and animal care. We also thank Mrs. Masako Kimura for typing this manuscript.

\section{References}

[1] Thomas, L. (1959). Discussion. In Cellular and humoral aspects of the hypersensitive states, p.529, 
Lawrence, H. S. (ed.), Hoeber-Harper, N. Y.

[2] Burnet, F. H. (1970). Immunological Surveillance. Pergamon Press, Sydney.

[3] Vandeputte, M., Eyssen, H., Sobis, H., and DeSomer, P. (1974). Induction of polyoma tumors in athymic nude mice. Int. J. Cancer, 14, 445-450.

[4] Allison, A. C., Monga, J. N., and Hammond, V. (1974). Increased susceptibility to virus oncogenesis of congenitally thymic-deprived nude mice. Nature (Lond.), 252, 746-747.

[5] Stutman, O. (1975). Delayed tumour appearance and absence of regression in nude mice infected with murine sarcoma virus. Nature (Lond.), 253, 142-144.

[6] Stutman, O. (1975). Tumor development after polyoma infection in athymic nude mice. J. Im. munol., 114, 1213-1217.

[7] Holland, J. M., Mitchell, T. J., Gipson, L. C., and Whitaker, M. S. (1978). Survival and cause of death in aging germfree athymic nude and normal inbred C3 Hf/He mice. J. Natl. Cancer Inst., 61, 1357-1361.

[8] Outzen, H. C., Custer, R. P., Eaton, G. J., and Prehn, R. T. (1975). Spontaneous and induced tumor incidence in germfree "nude" mice. $J$. Reticuloendothel. Soc., 17, 1-9.

[9] Stutman, O. (1974). Tumor development in im. munologically deficient nude mice after exposure to chemical carcinogens. In Proceedings of The First International Workshop on Nude Mice, pp. 257-264, Rygaad, J. and Povlsen, C. O. (eds.), Gustav Fischer Verlag, Stuttgart.

[10] Stutman, O. (1974). Tumor development after 3methylcholanthrene in immunologically deficient athymic-nude mice. Science, 183, 534-536.

[11] Stutman, O. (1979). Chemical carcinogenesis in nude mice: Comparison between nude mice from homozygous matings and heterozygous matings and effect of age and carcinogen dose. J. Natl. Cancer Inst., 62, 353-358.

[12] Anderson, L. M., Budinger, J. M., Maronpot, R. R., and Good, R. A. (1978). Transplacental lung tumorigenesis in the athymic mouse. Cancer Res., 38, 137-141.

[13] Anderson, L. M., Last-Barney, K., and Budinger, J. M. (1982). Sensitivity to carcinogenesis in nude mice : Skin tumors caused by transplacental exposure to ethylnitrosourea. Science, 218, 682-684.

[14] Anderson, L. M. and Rice, J. M. (1987). Tumorigenesis in athymic nude mouse skin by chemical carcinogens and ultraviolet light. J. Natl. Cancer Inst ., 78, 125-134.

[15] Shimkin, M. B. (1955). Pulmonary tumors in experimental animals. Adv. Cancer Res., 3, 223-267.

[16] De Benedictis, G., Maiorano, G., Chieco-Bianchi, L., and Fiore-Donati, L. (1962). Lung carcinogenesis by urethane in newborn, suckling, and adult Swiss mice. Brit. J. Cancer, 16, 686-689.

[17] Mirvish, S. S. (1968). The carcinogenic action and metabolism of urethan and N-hydroxyurethan. Adv. Cancer Res., 11, 1-42.

[18] Shimkin, M. B. and Stoner, G. D. (1975). Lung tumors in mice: Application to carcinogenesis bioassay. Adv. Cancer Res., 21, 1-58.

[19] Shimkin, M .B. and Polissar, M. J. (1955). Some quantitative observations on the induction and growth of primary pulmonary tumors in strain A mice receiving urethan. J. Natl. Cancer Inst., 16, 75-97.

[20] Herberman, R. B., Nunn, M. E., and Lavrin, D. H. (1975). Natural cytotoxic reactivity of mouse lymphoid cells against syngeneic and allogenic tumors. I. Distribution of reactivity and specificity. Int. J. Cancer, 16, 216-229.

[21] Sharp, A. K. and Colston, M. J. (1984). Elevated macrophage activity in nude mice. In Immune-Deficient Animals in Experimental Research, pp. 44-47, Sordat, B. (ed.), S. Karger, Basel.

[22] Bloom, J. L. and Falconer, D. S. (1964). A gene with major effect on susceptibility to induced lung tumors in mice. J. Natl. Cancer Inst., 33, 607-618.

[23] Malkinson, A. M., Nesbitt, M. N., and Skamene, E. (1985). Susceptibility to urethan-induced pulmonary adenomas between $\mathrm{A} / \mathrm{J}$ and $\mathrm{C} 57 \mathrm{BL} / 6 \mathrm{~J}$ mice : Use of $\mathrm{A} \times \mathrm{B}$ and $\mathrm{B} \times \mathrm{A}$ recombinant inbred lines indicating a three-locus genetic model. J. Natl. Cancer Inst., 75, 971-974.

[24] Heston, W. E. (1974). Genetics of Cancer. J. Her . edit., 65, 262-272.

[25] Engelse, L. D., Oomen, L. C. J. M., Vander Valk, M. A., Hart, A. A. M., Dux, A., and Emmelot, P. (1981). Studies on lung tumors. V. Susceptibility of mice to dimethylnitrosamine-induced tumor formation in relation to $\mathrm{H}-2$ haplotype. Int. J . Cancer, 28, 199 -208 .

[26] Moriwaki, K. and Miyashita, N. (1981). Effect of major histocompability $(\mathrm{H}-2)$ gene complex on the susceptibility to urethan induced lung tumor in mice. Ann. Rep. Natl. Inst. Genet. (Japan), 32, 38.

[27] Miyashita, N. and Moriwaki, N. (1987). H-2controlled genetic susceptibility to pulmonary adenomas induced by urethane and 4-nitro-quinoline 1-oxide in $\mathrm{A} / \mathrm{Wy}$ congenic strains. Jpn. J. Cancer Res. (Gann), 78, 494-498.

[28] Sichak, S. P. and O'Flaherty, E. J. (1984) . Consideration of the mechanism of pulmonary adenogenesis in urethane-treated Swiss mice. Toxicol. Appl. Phar. macol., 76, 397-402.

[29] Dahl, G. A., Miller, J. A., and Miller, E. C. (1978). Vinyl carbamate as a promutagen and a more carcinogenic analog of ethyl carbamate. Cancer Res., 38, 3793-3804.

[30] Miller, J. A. and Miller, E. C. (1983). The metabolic activation and nucleic acid adducts of naturally-occurring carcinogens : Recent results with ethyl carbamate and the spice flavors safrole and estragole. Brit. J . Cancer, 48, 1-15. 


\title{
ヌードマウスと正常マウスにおけるウレタン誘発肺腫瘍発生の比較
}

\author{
小林森・大津裕司・野田做子
}

放射線医学総合研究所生理病理研究部

化学物質による肺腫瘍の発生に対する免疫監視機 構の役割を解析する目的で, 14 16日齢の T細胞機能 を欠く $\mathrm{BALB} / \mathrm{c}$ ヌード $(n u / n u)$ マウスと，その機能 を有する同腹の $\mathrm{BALB} / \mathrm{c}(n u /+)$ マウスにウレタン を腹腔内投与し, 肺腫瘍発生の用量一反応相関性およ び経時的变化を比較検討した。用量一反応性の検討に は $n u / n u$ マウスと $n u /+$ マウスをそれぞれ 5 群に分 け，体重 $1 \mathrm{~g}$ 当たり0，0.25，0.5，1.0および $1.5 \mathrm{mg} の$ ウレタンを投与し， 6 力月後に全動物を屠殺し, 肺腫 瘍発生数を調べた。その結果, 各投与量に対する反応 性 (肺腫瘍発生) は $n u / n u$ マウスと $n u /+$ マウスでは ほほ同じであった。次に $0.5 \mathrm{mg} / \mathrm{g}$ 体重のウレタン投与 後, 28日から12カ月にかけて経時的にマウスを屠殺
し, 肺腫瘍の発生率と腫痬数を調べた。その結果, $n u /$ $n u$ マウス群および $n u /+$ マウス群での肺腫瘍発生率 は，6力月目ではそれぞれ $73 \% ， 80 \% て ゙ あ り ， 12$ 月 目では $96 \% ， 97 \% て ゙ ，$ 双方のマウス群間に差は見られ なかった。1匹当たりの平均肺腫煬数は, 両マウス群 共に経時的に同様の值で加算的に增加し，12 カ月後で は $n u / n u$ マウスでは4.8個, $n u /+$ マウスでは4.4個 であった。以上の結果から，T細胞機能を欠くヌード マウスは $n u /+$ マウスに比べて, ウレタンによる肺腫 瘍発生の頻度は高くなく, 今回のモデル実験からは, いわゆる免疫監視機構説を支持する結果は得られな かった。 